\title{
Microsatellite analysis of genetic diversity in Czech populations of European beech (Fagus sylvatica L.)
}

\author{
Dagmar Zádrapová, Jiří Korecký*, Jakub Dvořák, Zuzana \\ Faltinová and Jan Bílý
}

\begin{abstract}
Zádrapová, D., Korecký, J., Dvořák, J., Faltinová, S., Bílý, J. 2020. Microsatellite analysis of genetic diversity in Czech populations of European beech (Fagus sylvatica L.). - Forestry Studies | Metsanduslikud Uurimused 73, 64-76, ISSN 1406-9954. Journal homepage: http:/ / mi.emu.ee/forestry.studies
\end{abstract}

\begin{abstract}
European beech (Fagus sylvatica L.) is one of the most important broadleaved tree species in Europe both ecologically and economically. Nowadays, in the Czech Republic, beech is underrepresented in forest tree species composition, and there are tendencies to increase its proportion. When reintroducing beech, genetic variability, along with other factors, play a key role. The main aim of this study was to evaluate the genetic diversity of ten selected indigenous beech populations across the Czech Republic. Two hundred and fifty individuals were genotyped on 21 polymorphic nuclear microsatellite markers, which were amplified using two newly assembled multiplexes. According to the results, observed heterozygosity $\left(H_{o}\right)$ among populations ranged from 0.595 to 0.654 and expected heterozygosity $\left(H_{e}\right)$ from 0.650 to 0.678 . That is comparable with the findings in other European studies. The high discriminatory power of the assembled multiplexes was confirmed by calculating the Probability of Identity among both unrelated and related individuals. Principal Coordinate Analysis (PCoA) based on Nei's genetic distances revealed that there are genetic differences among populations resulting in three approximate clusters (geographically north, south-east, and south-west). Nevertheless, the results implicate that on a geographical scale of the Czech Republic, the distance is unlikely to be the primary driver of genetic differentiation.
\end{abstract}

Key words: multiplex SSRs PCR, genetic variation, local populations.

Authors' address: Faculty of Forestry and Wood Sciences, Czech University of Life Sciences Prague, Kamýcká 129, 165 00, Prague - Suchdol, Czech Republic; *korecky@fld.czu.cz

\section{Introduction}

European beech (Fagus sylvatica L.) is one of the most widespread broad-leaved tree species in Europe, covering circa 12 million ha of land (Buitelveld et al., 2007). It is characterized by an extensive ecological niche, high competitiveness and physiological tolerance against a wide range of environmental factors, making beech a vital tree species both ecologically and economically
(Dittmar et al., 2003; Pastorelli et al., 2003; Leuschner et al., 2006; Lefèvre et al., 2012). In many regions of Central Europe, including the Czech Republic, beech covered naturally large areas. However, due to medieval deforestation and revenue-oriented forest management, many of the natural beech stands have been replaced by spruce (Picea) or pine (Pinus) species (Paule, 1997; Hasenkamp et al., 2011). In the Czech Republic, the natural representation of beech

DOI: $10.2478 /$ fsmu-2020-0015

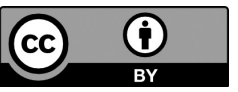

(c) 2020 by the authors. Licensee Estonian University of Life Sciences, Tartu, Estonia. This article is an open access article distributed under the terms and conditions of the Creative Commons Attribution (CC BY) license (http://creativecommons.org/licenses/by/4.0/). 
was $40.2 \%$ compared to its current deficient proportion of just $8.6 \%$ which represents 223,611 ha (Fulín et al., 2016; Ministry of Agriculture, 2019). Nowadays, however, there are trends to put beech back into the forests, and it is frequently used together with other broadleaves for reforestation (Tomášková, 2004). The recommended proportion of beech in the tree species composition makes 18\% (e.g. approximately 470,000 ha), which means a future increase of about 9.5\% (Ministry of Agriculture, 2019). The preferred seed sources should provide the genetic pre-conditions for the best possible adaptation to the respective local conditions and presumed climatic shifts (Hasenkamp et al., 2011; Gömöry et al., 2015). Mainly because of ongoing climate change, the study of genetic variation and differentiation of beech populations is crucial for determining the adaptive potential of the species (Jump et al., 2006a, 2006b; Sjölund \& Jump, 2015; Kempf \& Konnert, 2016). In the Czech Republic, supposedly native populations are often located in the border regions of the country. Moreover, these sources are usually under a particular degree of forest protection. Knowledge of the genetic structure of indigenous populations might reveal the significant indicator of the best-adapted populations for a given site. Therefore, efficient methods for reliable identification of potentially well-preadapted seeds are needed. In the past, beech has been studied by various genetic markers such as isozymes (Thiebaut et al., 1982; Comps et al., 1991; Degen \& Scholz, 1998; Božič \& Kutnar, 2012), Random Amplification of Polymorphic DNA (RAPD) and Amplified Fragment Length Polymorphism (AFLP) (Scalfi et al., 2004), nuclear, chloroplast and mitochondrial microsatellites (Pastorelli et al., 2003; Asuka et al., 2004; Vettori et al., 2004; Vornam et al., 2004; Magri et al., 2006; Hasenkamp et al., 2011; Lefèvre et al., 2012, Pluess \& Määttänen, 2013) and Single Nucleotide Polymorphism (SNP) (Seifert et al., 2012). Out of all the markers mentioned above, nu- clear microsatellite markers (SSRs, Simple Sequence Repeats) represent an ideal tool for studying genetic diversity, considering their high abundance in genomes, a high degree of polymorphism, neutrality and locus-specificity (Pastorelli et al., 2003). In the past, several studies used multiplexed microsatellite loci to determine genetic variability on a population level (Tanaka et al., 1999; Pastorelli et al., 2003; Asuka et al., 2004; Lefèvre et al., 2012; Plues \& Määttänen, 2013).

This paper presents the results of nuclear-microsatellite analyses of beech populations from ten regions in the Czech Republic. To evaluate their population genetics parameters, we used two newly modified multiplexes (13- and 8-plex). We focused on the following questions: (i) Are there significant differences between local beech populations across the Czech Republic? (ii) Can we eventually identify substantial differences among the targeted population? (iii) What is the discrimination power of our marker assemblage?

\section{Material and Methods}

\section{Study site and sampling}

We identified ten beech stands across the Czech Republic (Table 1, Figure 3) aiming at populations that are considered to be locally adapted and superior under local conditions. Each of the selected populations was represented either by 20 or 30 mature individuals according to the site characteristics, which turned into 250 tested individuals in total. Sampling was carried out in 2017. The minimal distance between sampled trees was $30 \mathrm{~m}$ to avoid sampling among closely related individuals (von Wühlisch, 2008). For each individual, we collected unburst buds and extracted the vascular cambium with a hole punch. Plant tissues were labeled appropriately and placed in plastic bags with silica gel. Then they were long-term stored in a freezer. 
Table 1. Stand-specific data of the samples.

\begin{tabular}{|c|c|c|c|c|c|}
\hline \multirow{2}{*}{$\begin{array}{l}\text { No. of } \\
\text { Population }\end{array}$} & \multirow{2}{*}{ Provenance Name } & \multirow{2}{*}{$\begin{array}{l}\text { Average Altitude } \\
\text { (m a.s.l.) }\end{array}$} & \multicolumn{2}{|c|}{ Geographic Coordinates } & \multirow{2}{*}{ No. of Samples } \\
\hline & & & latitude & longitude & \\
\hline 1 & Frýdlant & 441 & $50^{\circ} 52^{\prime} 24.1^{\prime \prime} \mathrm{N}$ & $15^{\circ} 06^{\prime} 36.1^{\prime \prime} \mathrm{E}$ & 20 \\
\hline 2 & Kladská & 755 & $50^{\circ} 00^{\prime} 11.8^{\prime \prime} \mathrm{N}$ & $12^{\circ} 38^{\prime} 55.5^{\prime \prime} \mathrm{E}$ & 20 \\
\hline 3 & Litvínov & 794 & $50^{\circ} 36^{\prime} 46.8^{\prime \prime} \mathrm{N}$ & $13^{\circ} 23^{\prime} 14.5^{\prime \prime} \mathrm{E}$ & 20 \\
\hline 4 & Boubín & 916 & $49^{\circ} 09^{\prime} 05.5^{\prime \prime} \mathrm{N}$ & $13^{\circ} 40^{\prime} 03.2^{\prime \prime} \mathrm{E}$ & 20 \\
\hline 5 & Nové Hrady & 863 & $48^{\circ} 39^{\prime} 46.6^{\prime \prime} \mathrm{N}$ & $14^{\circ} 40^{\prime} 51.0^{\prime \prime} \mathrm{E}$ & 20 \\
\hline 6 & Hluboká & 538 & $49^{\circ} 06^{\prime} 24.3^{\prime \prime} \mathrm{N}$ & $14^{\circ} 29^{\prime} 51.6^{\prime \prime} \mathrm{E}$ & 30 \\
\hline 7 & Jeseník & 652 & $50^{\circ} 11^{\prime} 34.1^{\prime \prime} \mathrm{N}$ & $17^{\circ} 13^{\prime} 55.0^{\prime \prime} \mathrm{E}$ & 30 \\
\hline 8 & Frýdek Místek & 839 & $49^{\circ} 31^{\prime} 44.7^{\prime \prime} \mathrm{N}$ & $18^{\circ} 28^{\prime} 28.6^{\prime \prime} \mathrm{E}$ & 30 \\
\hline 9 & Luhačovice & 479 & $49^{\circ} 03^{\prime} 06.0^{\prime \prime} \mathrm{N}$ & $18^{\circ} 04^{\prime} 19.0^{\prime \prime} \mathrm{E}$ & 30 \\
\hline 10 & Lanškroun & 573 & $49^{\circ} 56^{\prime} 07.4^{\prime \prime} \mathrm{N}$ & $16^{\circ} 30^{\prime} 33.2^{\prime \prime} \mathrm{E}$ & 30 \\
\hline
\end{tabular}

\section{DNA extraction}

Initially, both the vascular cambium and leaf buds were tested for DNA extraction. Even though both types of tissues provided identical genetic profiles, we decided to extract the DNA from the buds, because of its higher purity and yield. From each individual, approximately 2 or 3 unsterilized fresh buds were cut into small pieces and placed into $2 \mathrm{~mL}$ safe-lock tubes (Eppendorf, Germany). Two $3 \mathrm{~mm}$ tungsten beads were added in each tube and frozen in liquid nitrogen before grinding $(1 \mathrm{~min}, 30 \mathrm{~Hz})$ using a mixer mill MM400 (Retsch, Haan, Germany). Genomic DNA was extracted with the Geneaid $\AA$ Genomic DNA Mini Kit (Plant) according to the manufacturer's instructions with a minor modification in the lysis step (60 min of incubation phase). The DNA quantity and quality were measured with a NanoDrop® 2000 spectrophotometer (Thermo Fisher Scientific, Waltham, MA, USA). The quality of the DNA was verified using $1.5 \%$ agarose gel electrophoresis. For subsequent Polymerase Chain Reaction (PCR) steps, we diluted all DNA samples to a working concentration of $20 \mathrm{ng} / \mu \mathrm{L}$.

\section{Multiplex PCR optimization}

After amplification in single reactions, from preselected microsatellite loci, we excluded those which were difficult to evaluate or of low polymorphism ( $<4$ alleles), with poor amplification quality or low signal intensity. This led to a total number of 21 highly validated fluorescently labeled genomic markers - mfc5, mfc7 a mfc11 (Tanaka et al., 1999), FS1-03 (Pastorelli et al., 2003), sfc0036 (Asuka et al., 2004), concat14_A_0, EMILY_A_0, csolfagus_05, csolfagus_06, csolfagus_19, csolfagus_29, csolfagus_31, DE576_A_0, ERHBI_A_0, EEU75_A_0, DZ447_A_0 a DUKCT_A_0 (Lefèvre et al., 2012), Fagsyl_002929, Fagsyl_003849, Fagsyl_001018 and Fagsyl_003093 (Pluess \& Määttänen, 2013) as presented in Table 2. The final loci selection was divided into two multiplexes (13- and 8-plex) according to their size ranges and PCR amplification compatibility. An issue of different annealing temperatures among selected primers was considerably decreased when using Type-it@ Microsatellite PCR kit (Qiagen, Hilden, Germany) for PCR amplification. Both multiplexes showed clear patterns and consistent amplification profiles. 


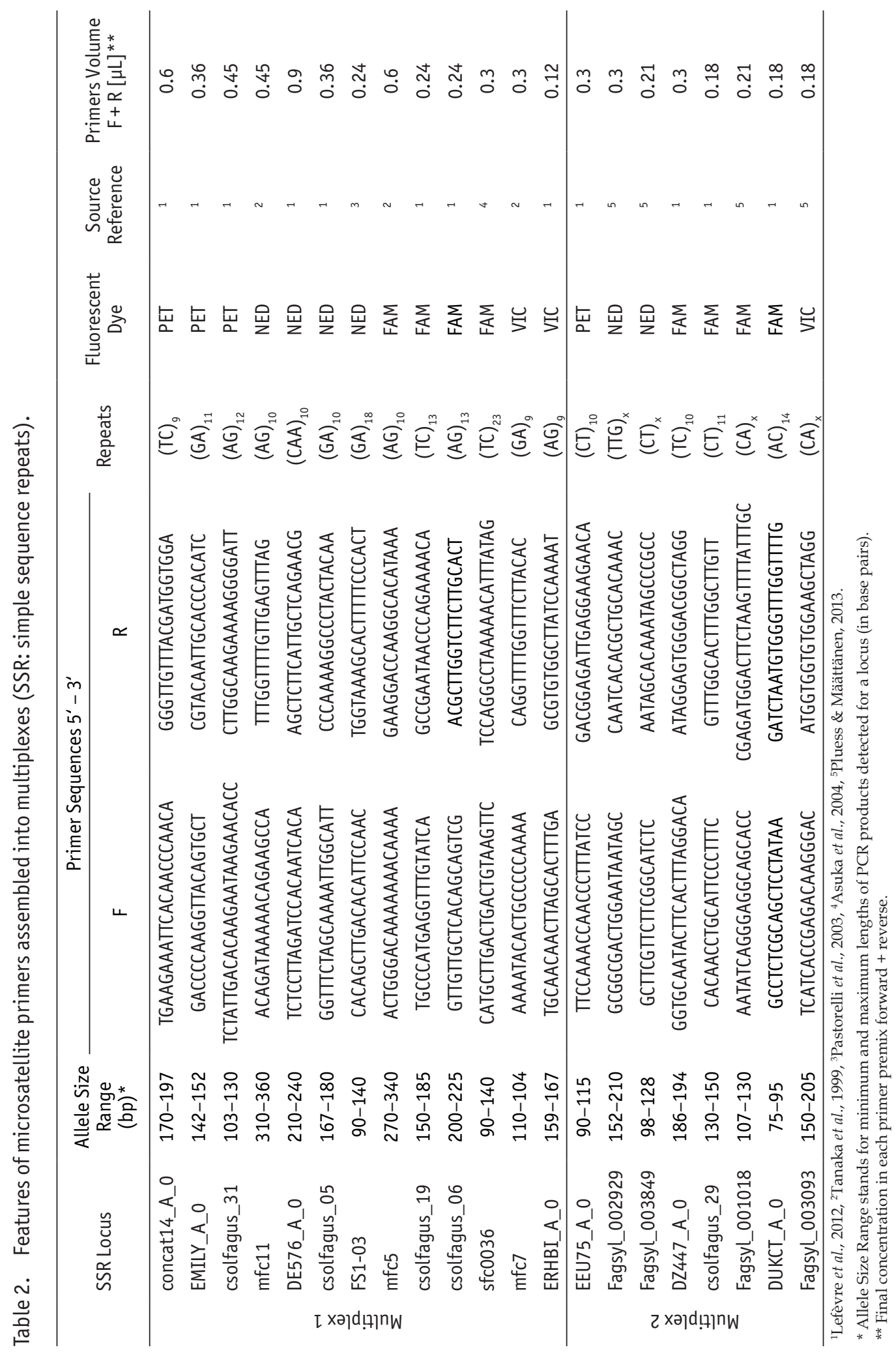




\section{PCR}

Amplification was performed in two multiplex polymerase chain reactions (Mastercycler ${ }^{\circledR}$ nexus, Eppendorf, Germany). The PCR mixture for multiplex 1 was performed in a total volume of $11.4 \mu \mathrm{L}$ containing $1 \mu \mathrm{L}$ template DNA $(c=20 \mathrm{ng} / \mu \mathrm{L})$, $5.7 \mu \mathrm{L}$ of Type-it ${ }^{\circledR}$ solution (Qiagen, Hilden, Germany), $0.26 \mu \mathrm{L}$ sterile water and a total volume of $4.44 \mu \mathrm{L}$ primer premix. The PCR for multiplex 2 was performed in a total volume of $6 \mu \mathrm{L}$, consisting of $1 \mu \mathrm{L}$ template DNA ( $c=20 \mathrm{ng} / \mu \mathrm{L})$, $3 \mu \mathrm{L}$ of Type-it ${ }^{\circledR}$ solution (Qiagen, Hilden, Germany), $0.14 \mu \mathrm{L}$ of sterile water and $1.86 \mu \mathrm{L}$ of primer premix. Concentrations and label dyes for each primer pair in the final primer premix are shown in Table 2. Both multiplexes had the same PCR conditions as follows: an initial incubation ( $5 \mathrm{~min}$ at $95^{\circ} \mathrm{C}$ ) was followed by 33 cycles consisting of the denaturation $\left(45 \mathrm{~s}\right.$ at $\left.95^{\circ} \mathrm{C}\right)$, annealing $\left(45 \mathrm{~s}\right.$ at $\left.60^{\circ} \mathrm{C}\right)$ and extension phase $\left(60 \mathrm{~s}\right.$ at $\left.72{ }^{\circ} \mathrm{C}\right)$. Amplification was terminated with the final extension step $\left(30 \mathrm{~min}\right.$ at $72{ }^{\circ} \mathrm{C}$ ). The fluorescently labelled PCR products, together with an internal size standard (GMC-GT500 LIZ) were processed on a 3500 Series Genetic Analyzer ${ }^{\circledR}$ (Applied Biosystems, Foster City, CA, USA).

\section{Data analysis}

Allele identification and genotyping were done using the GeneMarker ${ }^{\circledR}$ Fragment Analysis software (SoftGenetics, State College, PA, USA). All alleles were subsequently checked manually to minimize genotyping errors. Allele frequency analysis was performed using CERVUS v. 3.0.7 (Kalinowski et al., 2007) in order to identify the number of alleles per locus. Also, summary statistics were calculated for each locus, such as observed heterozygosity $\left(H_{0}\right)$, expected heterozygosity $\left(H_{e}\right)$, polymorphic information content $(P I C)$ and fixation in$\operatorname{dex}\left(F_{I S}\right)$.

For the analysis of population genetic parameters, we used software GenAIEx v. 6.5 (Peakall \& Smouse, 2006, 2012). To group populations according to their pairwise distances in a distance matrix, a Principal Coordinate Analysis (PCoA) was carried out. The distribution of total variance at different hierarchical levels was quantified with an Analysis of Molecular Variance (AMOVA). We also evaluated the discrimination power of assembled multiplexes. Therefore, the Probability of Identity $(P I)$ for unrelated and related $\left(P I_{\text {sibs }}\right)$ individuals was calculated, which represents a measure for the statistical power of individual identification with the chosen marker combination (Hartl \& Clark, 2007).

\section{Results}

\section{Allele frequency analysis}

All samples $(\mathrm{n}=250)$ were genotyped on 21 SSR loci grouped into two multiplexes (Table 3). The number of genotyped individuals on each locus $(N)$ varies because some of the samples did not show any apparent alleles on a particular locus. We did not detect vegetative copies among the samples. We observed the most significant dropout of samples (56 individuals) on locus Fagsyl_003093.

The total amount of 208 alleles was detected. The number of alleles per locus $(k)$ ranged from 4 to 22 with a mean value of $9.905 \pm 4.098$. The highest count of alleles per locus (22) was found at mfc5 where we also observed significant deviation from Hardy-Weinberg equilibrium. The expected heterozygosity $\left(H_{e}\right)$ ranged from 0.436 (csolfagus_29) to 0.906 (mfc5), with an average of $0.685 \pm 0.134$. The observed heterozygosity $\left(H_{0}\right)$ ranged from 0.216 (Fagsyl_003093) to 0.859 (csolfagus_06) with an average of $0.625 \pm 0.183$. The mean polymorphic information content (PIC) across all loci was $0.649 \pm 0.146$. Most loci did not show a significant deviation from the expected Hardy-Weinberg frequencies, except 5 loci (mfc11, FS1-03, mfc5, Fagsyl_001018, Fagsyl_003093). We also 
detected 6 loci with a significant occurrence of null alleles ( $a=0.05$, marked bold in Table 3).

Private alleles were found in all analyzed populations except populations 5 and 10 . The frequencies of rare alleles were generally low and ranged between 0.017 and 0.077 , with an average of $0.033 \pm 0.019$. The highest amount of private alleles was observed in populations 1 and 9. Private alleles with the highest frequencies were found in population 2 .

Table 3. Locus-specific parameters.

\begin{tabular}{|c|c|c|c|c|c|c|c|}
\hline Locus & $k$ & $N$ & $H_{o}$ & $H_{e}$ & PIC & $H W$ & $F($ Null) \\
\hline concat14_A_0 & 4 & 249 & 0.474 & 0.494 & 0.461 & NS & 0.0229 \\
\hline EMILY_A_0 & 6 & 249 & 0.763 & 0.770 & 0.731 & NS & 0.0009 \\
\hline csolfagus_31 & 13 & 249 & 0.855 & 0.858 & 0.842 & NS & -0.0005 \\
\hline $\mathrm{mfc} 11$ & 9 & 249 & 0.353 & 0.616 & 0.594 & $* * *$ & 0.2575 \\
\hline DE576_A_0 & 7 & 248 & 0.710 & 0.669 & 0.613 & NS & -0.0325 \\
\hline csolfagus_05 & 8 & 249 & 0.675 & 0.679 & 0.639 & NS & 0.0068 \\
\hline FS1-03 & 14 & 246 & 0.528 & 0.622 & 0.594 & ** & 0.088 \\
\hline $\mathrm{mfc5}$ & 22 & 249 & 0.669 & 0.906 & 0.897 & $* *$ & 0.1504 \\
\hline csolfagus_19 & 13 & 249 & 0.803 & 0.844 & 0.824 & NS & 0.0262 \\
\hline csolfagus_06 & 12 & 248 & 0.859 & 0.867 & 0.851 & NS & 0.0042 \\
\hline sfc0036 & 8 & 248 & 0.786 & 0.772 & 0.744 & NS & -0.0114 \\
\hline $\mathrm{mfc} 7$ & 9 & 249 & 0.578 & 0.596 & 0.559 & NS & 0.134 \\
\hline ERHBI_A_0 & 6 & 249 & 0.514 & 0.530 & 0.491 & NS & 0.0163 \\
\hline EEU75_A_0 & 11 & 245 & 0.808 & 0.805 & 0.777 & NS & -0.0040 \\
\hline Fagsyl_002929 & 11 & 247 & 0.765 & 0.729 & 0.693 & NS & -0.0269 \\
\hline Fagsyl_003849 & 14 & 247 & 0.814 & 0.808 & 0.783 & NS & -0.0034 \\
\hline DZ447_A_0 & 4 & 245 & 0.592 & 0.593 & 0.545 & NS & 0.0051 \\
\hline csolfagus_29 & 8 & 248 & 0.435 & 0.436 & 0.400 & NS & -0.001 \\
\hline Fagsyl_001018 & 9 & 246 & 0.390 & 0.656 & 0.608 & $* * *$ & 0.2696 \\
\hline DUKCT_A_0 & 8 & 246 & 0.537 & 0.569 & 0.449 & NS & 0.0291 \\
\hline Fagsyl_003093 & 12 & 194 & 0.216 & 0.571 & 0.530 & $* * *$ & 0.4491 \\
\hline Mean & 9.905 & 245 & 0.625 & 0.685 & 0.649 & & \\
\hline$S D$ & 4.098 & & 0.183 & 0.134 & 0.146 & & \\
\hline$S E$ & 0.894 & & 0.040 & 0.029 & 0.032 & & \\
\hline
\end{tabular}

Number of allele per locus $(k)$, number of individuals genotyped on given locus $(N)$, observed heterozygosity $\left(H_{0}\right)$, expected heterozygosity $\left(H_{e}\right)$, polymorphic information content $(P I C)$, deviation from Hardy-Weinberg equilibrium ( $H W$, level of significance: ${ }^{* * *} a=0.001 .{ }^{* *} a=0.01$, NS - not significant), estimation of null allele frequency $(F(\mathrm{Null}))$, significant estimates are marked bold), standard deviation (SD), standard error (SE).

The discriminatory power of multiplexed SSRs markers

In order to evaluate the discriminatory power of used multiplexes, the Probability of Identity (PI, GenAlEx v. 6.5) was carried out. Figure 1 shows the decreasing probability of identity with an increasing number of markers used (e.g., the effect of cumulative markers).

In our study, we also evaluated a modified version $P I_{\text {sib }}$ for estimating the probability of identity when related individuals are included in the sample. When using 5 randomly selected loci, the probability of 
statistically significant distinction was for unrelated individuals $P I=7.2 \times 10^{-4}$ and for related individuals $P I_{\text {sib }}=0.04$. With 8 loci used the probability decreases to $P I=3.13 \times 10^{-7}$ and $P I_{\text {sib }}=2.2 \times 10^{-2}$. With 15 loci the probability further declines to $P I=4.97 \times 10^{-15}$ and $P I_{\text {sib }}=3.78 \times 10^{-6}$. For an entire set of 21 loci, the observed PI for un- related individuals was $P I=1.85 \times 10^{-20}$ and for related individuals $P I_{\text {sib }}=2.77 \times 10^{-8}$. These values confirm a high discriminatory power of used multiplexes even when family structures are expected among samples and the discriminatory power of loci is therefore significantly lower.

Probability of Identity

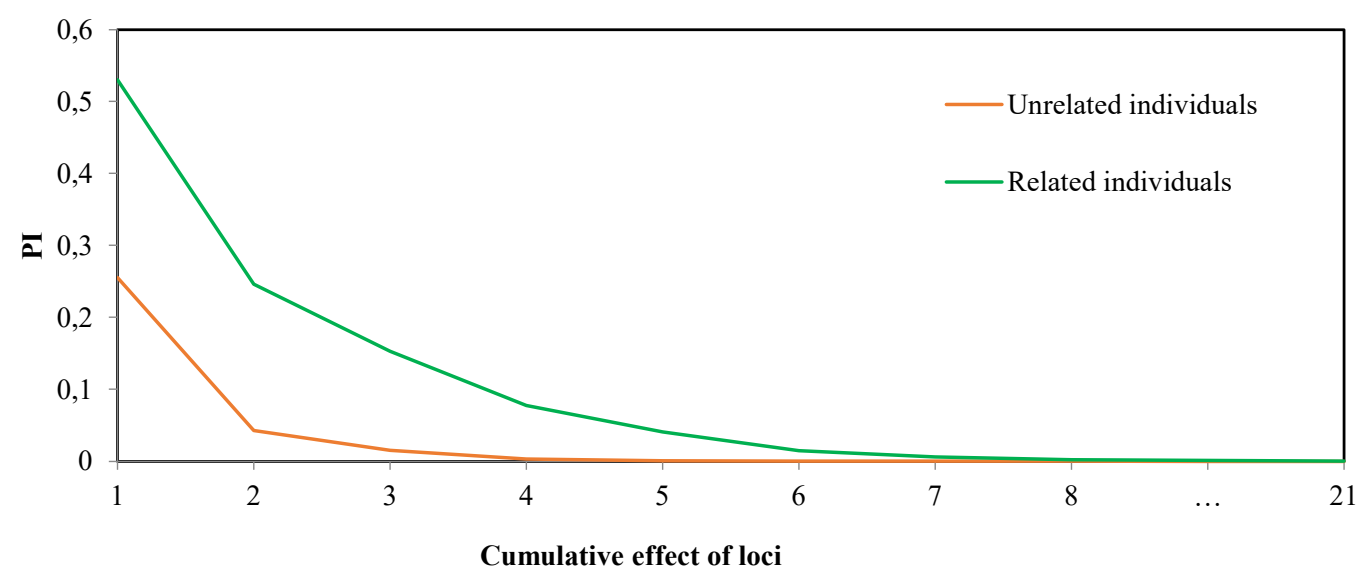

Figure 1. The discriminatory power of loci expressed by Probability of Identity $(P I)$ for unrelated individuals (orange line) and related individuals (green line).

Intra and interpopulation genetic diversity

The parameter of observed heterozygosity $\left(H_{0}\right)$ among populations ranged from 0.595 (Pop. 3) to 0.654 (Pop. 9) with the mean value of $0.625 \pm 0.014$. Expected heterozygosity $\left(H_{e}\right)$ ranged from 0.651 (Pop. 6) to 0.678 (Pop. 8) with the mean value of $0.664 \pm 0.010$.

The Principal Coordinate Analysis was performed based on genetic distances between the populations (e.g. the pairwise population matrix of Nei's genetic distance, Table 5). The result of PCoA is presented in Figure 2. The first two coordinates explain $35 \%$ of the total variation. PCoA sorted the populations in three groups, which can be simplified as south-west (Pops. 5, 4, 2, 3 and 7), north (Pops. 1 and 10), and southeast (Pops. 6, 9 and 8). Population 9 was the most distant from the others. The approximate regionalization of the populations is shown in Figure 3. However, in the scale of the Czech Republic, the geographical distance cannot be seen as the main driver of the genetic variation between the tested indigenous populations. AMOVA indicated that $98 \%$ of total molecular variance occurs within populations. Only $2 \%$ of the variation can be observed on an interpopulation level. It corresponds with the previous findings that a significant part of the genetic variability of forest trees is attributable to the intrapopulation level. 
Table 4. Estimations of population parameters.

\begin{tabular}{|c|c|c|c|c|c|c|c|c|}
\hline Population & & $N$ & $N_{a}$ & $N_{e}$ & $I$ & $H_{0}$ & $H_{e}$ & $F$ \\
\hline \multirow{2}{*}{1} & Mean & 19.524 & 6.905 & 3.925 & 1.447 & 0.635 & 0.674 & 0.074 \\
\hline & $S E$ & 0.290 & 0.581 & 0.522 & 0.102 & 0.046 & 0.030 & 0.042 \\
\hline \multirow[t]{2}{*}{2} & Mean & 19.571 & 6.476 & 3.583 & 1.414 & 0.629 & 0.662 & 0.072 \\
\hline & $S E$ & 0.335 & 0.550 & 0.339 & 0.093 & 0.057 & 0.034 & 0.063 \\
\hline \multirow{2}{*}{3} & Mean & 19.381 & 6.238 & 3.427 & 1.363 & 0.595 & 0.650 & 0.089 \\
\hline & $S E$ & 0.288 & 0.530 & 0.335 & 0.095 & 0.047 & 0.033 & 0.054 \\
\hline \multirow[t]{2}{*}{4} & Mean & 19.667 & 6.571 & 3.627 & 1.410 & 0.623 & 0.667 & 0.069 \\
\hline & $S E$ & 0.159 & 0.500 & 0.364 & 0.091 & 0.049 & 0.032 & 0.054 \\
\hline \multirow[t]{2}{*}{5} & Mean & 19.810 & 6.667 & 3.625 & 1.416 & 0.632 & 0.664 & 0.045 \\
\hline & $S E$ & 0.190 & 0.618 & 0.383 & 0.095 & 0.048 & 0.032 & 0.054 \\
\hline \multirow{2}{*}{6} & Mean & 29.381 & 6.905 & 3.549 & 1.393 & 0.607 & 0.651 & 0.082 \\
\hline & $S E$ & 0.288 & 0.589 & 0.417 & 0.098 & 0.044 & 0.032 & 0.042 \\
\hline \multirow{2}{*}{7} & Mean & 29.857 & 7.238 & 3.792 & 1.439 & 0.623 & 0.667 & 0.064 \\
\hline & $S E$ & 0.143 & 0.617 & 0.419 & 0.104 & 0.044 & 0.035 & 0.046 \\
\hline \multirow{2}{*}{8} & Mean & 29.667 & 7.381 & 3.879 & 1.484 & 0.630 & 0.678 & 0.064 \\
\hline & $S E$ & 0.333 & 0.674 & 0.502 & 0.099 & 0.039 & 0.030 & 0.046 \\
\hline \multirow{2}{*}{9} & Mean & 29.190 & 6.905 & 3.501 & 1.415 & 0.654 & 0.670 & 0.041 \\
\hline & $S E$ & 0.190 & 0.625 & 0.290 & 0.088 & 0.043 & 0.028 & 0.038 \\
\hline \multirow{2}{*}{10} & Mean & 29.143 & 6.905 & 3.648 & 1.419 & 0.619 & 0.662 & 0.062 \\
\hline & $S E$ & 0.469 & 0.625 & 0.419 & 0.098 & 0.042 & 0.032 & 0.046 \\
\hline \multirow{2}{*}{ Total } & Mean & 24.519 & 6.819 & 3.655 & 1.420 & 0.625 & 0.664 & 0.066 \\
\hline & $S E$ & 0.352 & 0.185 & 0.126 & 0.030 & 0.014 & 0.010 & 0.015 \\
\hline
\end{tabular}

Sample size $(N)$, mean number of alleles per locus $\left(N_{a}\right)$, effective number of alleles $\left(N_{e}\right)$, mean Shannon's information index $(I)$, observed heterozygosity $\left(H_{0}\right)$, expected heterozygosity $\left(H_{e}\right)$, mean fixation index $(F)$.

Principal Coordinates (PCoA)

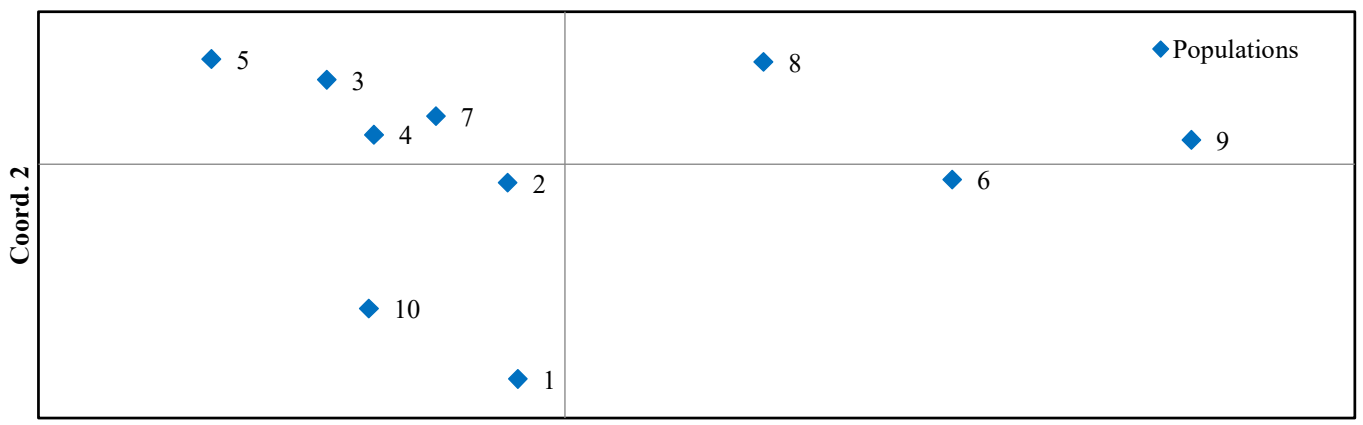

Coord. 1

Figure 2. Principal Coordinate Analysis (PCoA) of the populations 1-10 (further described in Table 1). 
Table 5. Nei's genetic distances between the provenances (Nei, 1972, 1987)

\begin{tabular}{cccccccccc|c}
\hline 1 & 2 & 3 & 4 & 5 & 6 & 7 & 8 & 9 & 10 & \\
\hline 0.000 & & & & & & & & & & 1 \\
0.067 & 0.000 & & & & & & & & & 2 \\
0.071 & 0.078 & 0.000 & & & & & & & & 3 \\
0.064 & 0.061 & 0.069 & 0.000 & & & & & & & 4 \\
0.078 & 0.061 & 0.064 & 0.049 & 0.000 & & & & & & 5 \\
0.062 & 0.070 & 0.076 & 0.061 & 0.077 & 0.000 & & & & & 6 \\
0.064 & 0.059 & 0.053 & 0.051 & 0.062 & 0.067 & 0.000 & & & & 7 \\
0.082 & 0.062 & 0.064 & 0.062 & 0.067 & 0.056 & 0.049 & 0.000 & & & 8 \\
0.079 & 0.075 & 0.088 & 0.081 & 0.091 & 0.056 & 0.074 & 0.057 & 0.000 & & 9 \\
0.055 & 0.065 & 0.074 & 0.065 & 0.072 & 0.079 & 0.060 & 0.061 & 0.087 & 0.000 & 10 \\
\hline
\end{tabular}

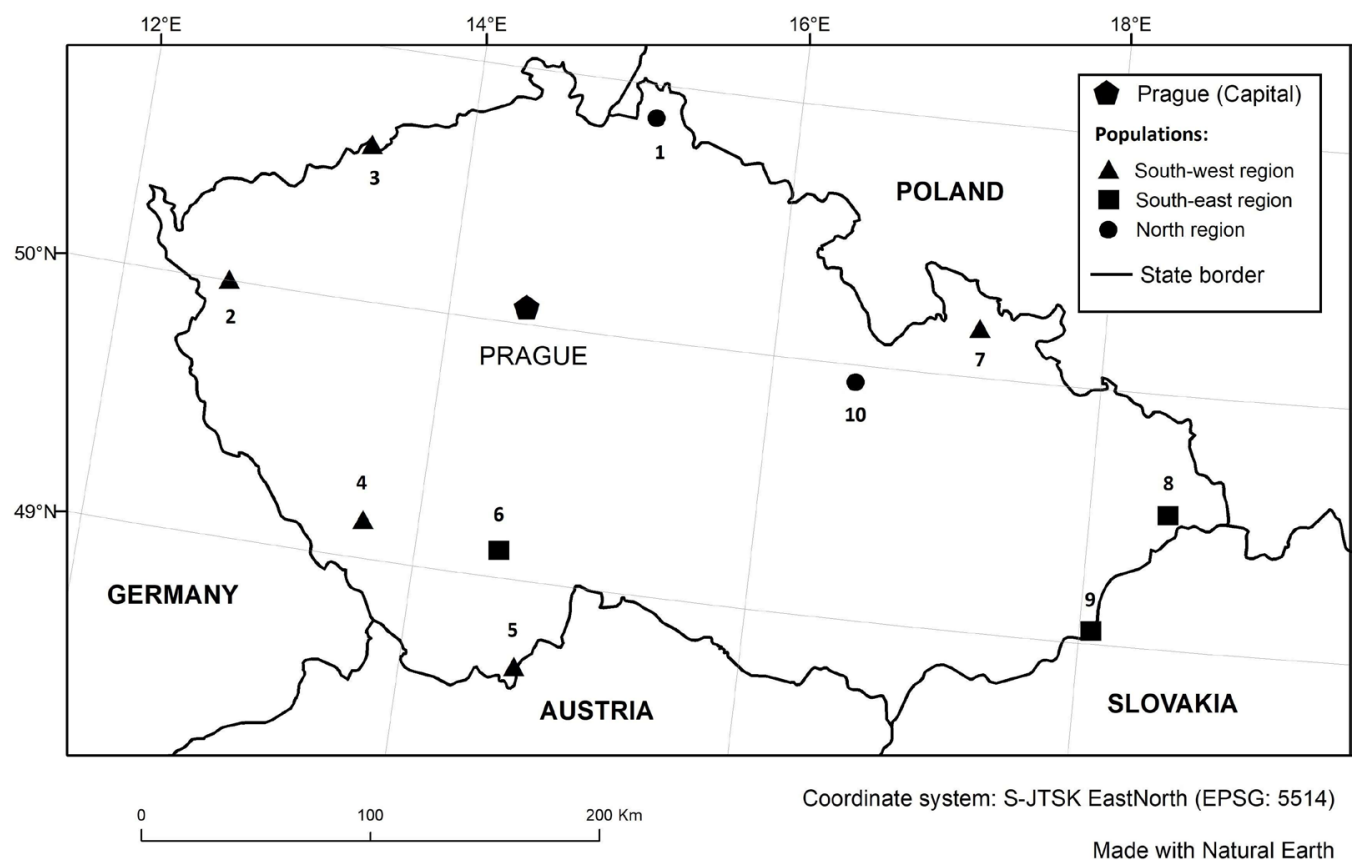

Figure 3. Populations 1-10 divided into three regions by PCoA (populations further described in Table 1).

\section{Discussion}

The mean value of observed heterozygosity $\left(H_{o}\right)$ among all 21 loci was $0.625 \pm 0.183$, expected heterozygosity $\left(H_{e}\right)$ was $0.685 \pm 0.134$. These values resemble other authors - Vornam et al. (2004) who observed $H_{o}=0.572$ and $H_{e}=0.765$ on 4 loci, Kempf \& Konnert (2016) $H_{0}=0.698$ and
$H_{e}=0.701$ on 10 loci, Hasenkamp et al. (2011) $H_{o}=0.663$ and $H_{e}=0.750$ and for the other study site $H_{o}=0.667$ and $H_{e}=0.776$ on 6 loci, Dounavi et al. (2016) $H_{0}=0.578$ and $H_{e}=0.604$ on 9 loci and Pluess \& Määttänen (2013) $H_{o}=0.564$ and $H_{e}=0.616$ on 18 loci. Slightly higher values observed Pastorelli et al. (2003) $H_{o}=0.727$ and $H_{e}=0.752$ on 7 loci and Lefèvre et al. (2012) $H_{0}^{e}=0.727$ and 
$H_{e}=0.695$ on 16 loci. A similar study in the Czech Republic was carried out by Cvrčková et al. (2017). They evaluated 390 beech individuals from 13 populations on 12 SSR markers where seven loci were identical with the ones we used in our study. They observed $H_{o}=0.702$ and $H_{e}=0.755$.

The most variable locus was mfc5, as previous studies have shown (Vornam et al., 2004; Hasenkamp et al., 2011). However, we also observed a deviation from Hardy-Weinberg equilibrium on this locus as well as a higher rate of null alleles occurrence $(F($ Null $)=0.1504)$. Null alleles above the threshold $a=0.05$ were also observed on loci mfc11, FS1-03, mfc7, Fagsyl_001018 and Fagsyl_003093. As confirmed in a review assembled by Janković et al. (2019), in many studies, null alleles were commonly observed on both mfc5 and FS1-03. Besides those, one study observed null alleles also on loci csolfagus_06, csolfagus_19 and csolfagus_31 where we failed to do so. Loci mfc11, FS1-03, mfc5, Fagsyl_001018 and Fagsyl_003093 exhibited high $\mathrm{F}_{\text {IS }}$ values. During scoring locus csolfagus_05 exhibited split peaks and locus Fagsyl_003093 created an artefact allele. Loci sfc0036 (Asuka et al., 2004), mfc5, $\mathrm{mfc} 7$ and mfc11 (Tanaka et al., 1999) were originally developed for related species Fagus crenata Fagus Blume and successfully used also for F. japonica Maxim. and F. sylvatica L.. It can be due to the fact that species within the genus $\mathrm{Fa}$ gus are very closely related (Tanaka et al., 1999).

$P I$ and $P I_{\text {sib }}$ analysis confirmed the high discriminatory power of both newly assembled multiplexes, and their ability to identify particular individuals. In analogous studies mentioned above, between 4 and 18 loci were used to genotype the individuals. In their study, Lefèvre et al. (2012) estimated PI for 16 loci $2.1 \times 10^{-8}$ and stated that this probability of finding two randomly matching genotypes is extremely low. In our study, we reached this level of $P I$ by using nine loci for unrelated and 21 loci for related individuals.
The PCoA analysis clustered studied indigenous populations into three approximate regions, geographically roughly corresponding to north, south-east and southwest. However, on the scale of the Czech Republic, distance cannot be considered as a significant criterion of population clustering. Long-term local adaptive processes are more likely to cause it.

Significant differences in observed heterozygosity within populations have not been detected. In general, the genetic diversity of the investigated populations was similar to populations across Central Europe. In our study $H_{0}$ range was 0.595 0.654 and $H_{e}$ range was $0.650-0.678$ which is comparable with the results of Dounavi et al. (2016) who observed the mean values of $H_{o}=0.578$ and $H_{e}=0.604$ among stands in southern Germany (Bavaria), Croatia, Bulgaria and Greece. Slightly higher values observed Kempf \& Konnert (2016) among stands in Poland where northern ecotypes exhibited $H_{o}=0.697$ and $H_{e}=0.706$, southern ecotypes $H_{o}=0.705$ and $H_{e}=0.701$ and overall $H_{o}=0.701$ and $H_{e}=0.704$. In the Czech Republic, Cvrčková et al. (2017) observed values of $H_{o}=0.697$ and $H_{e}=0.765$. In all these studies, differences between the observed and expected values of heterozygosity of studied populations were rather small. Across the studied populations, the highest number of private alleles was found on locus Fagsyl_003093, followed by loci Fagsyl_003849, mfc5 and csolfagus_29. Cvrčková et al. (2017) observed the highest number of private alleles in a population which was geographically very close to population 9 in our study and which also exhibited the highest number of private alleles. This may indicate a bigger genetic differentiation of beech individuals in this region which is also shown in the PCoA analysis (Figure 2).

AMOVA showed that $98 \%$ of total variability is observed on the intrapopulation level, only $2 \%$ occurs among the populations. This result is in agreement with previous studies as well, for example, 
Kempf \& Konnert (2016) observed 93\% of total variation within populations and 5\% among them and $2 \%$ between observed regions. As previous findings suggest, little differentiation on interpopulation level might be due to an extensive gene flow between beech populations over long distances (Wang, 2004; Piotti et al., 2012).

\section{Conclusions}

The results presented in this paper offer an insight into the genetic diversity of indigenous populations of European beech on the territory of the Czech Republic where only a few such studies have been done so far. Although the majority of detected variance is not attributable to a particular population, the evaluation of allelic parameters (heterozygosity, allelic diversity) is crucial and should not be omitted. Genetic variability, especially during artificial reforestation and the ongoing effort to increase the percentage of beech in the forests, should be carefully considered. It gains even more importance in the context of the continuing climate change, which is highly challenging for the adaptive and survival potential of species. In general, maximizing genetic diversity during artificial reforestation might prevent gene pool reduction and thus indirectly maintain allelic forms with higher fitness levels under shifted climatic conditions. Moreover, we confirmed that a well-optimized set of nuclear microsatellite markers is a useful and robust tool for the examination of genetic structure.

Acknowledgments. The project was financially supported by the Grant Agency of the Forests of the Czech Republic, state enterprise (Grant number 8/2016). Research activities were also partially funded by the Internal Grant Agency from the Faculty of Forestry and Wood Sciences (Grant number 43950/1312/3147), Czech University of Life Sciences Prague.
Conflicts of interests. The authors declare no conflict of interests. The funders had no role in the design of the study, in the collection analyses, or interpretation of data, in the writing of the manuscript, or in the decision to publish the results.

\section{References}

Asuka, Y., Tani, N., Tsumura, Y., Tomaru, N. 2004. Development and characterization of microsatellite markers for Fagus crenata Blume. - Molecular Ecology Notes, 4, 101-103. https:/ / doi.org/10.1046/j.1471-8286.2003.00583.x.

Božič, G., Kutnar, L. 2012. Genetic variability of two Fagus sylvatica (L.) populations in the South-Western edge of the Panonnian plain. Acta Silvatica et Lignaria Hungarica, 8, 75-86.

Buiteveld, J., Vendramin, G.G., Leonardi, S., Kamer, K., Geburek, T. 2007. Genetic diversity and differentiation in European beech (Fagus sylvatica L.) stands varying in management history. - Forest Ecology and Management, 247, 98-106. https://doi.org/10.1016/j. foreco.2007.04.018.

Comps, B., Thiebaut, B., Sugar, I., Trinajstic, I., Plazibat, M. 1991. Genetic variation of the Croatian beech stands (Fagus sylvatica L.): spatial differentiation in connection with the environment. - Annals of Forest Science, 48, 1528. https:/ / doi.org/10.1051/forest:19910102.

Cvrčková, H., Máchová, P., Poláková, L., Trčková, O. 2017. Evaluation of the genetic diversity of selected Fagus sylvatica L. populations in the Czech Republic using nuclear microsatellites. - Journal of Forest Science, 2, 53-61. https:/ / doi.org/10.17221/88/2016-JFS

Degen, B., Scholz, F. 1998. Spatial genetic differentiation among populations of European beech (Fagus sylvatica L.) in western Germany as identified by geostatistical analysis. - Forest Genetics, 5, 191-199.

Dittmar, C., Zech, W., Elling, W. 2003. Growth variations of Common beech (Fagus sylvatica L.) under different climatic and environmental conditions in Europe - A dendroecological study. - Forest Ecology and Management, 173, 63-78. https://doi.org/10.1016/S03781127(01)00816-7.

Dounavi, A., Netzer, F., Celepirovic, N., Ivanković, M., Burger, J., Figueroa, A.G., Schön, S., Simon, J., Cremer, E., Fussi, B., Konnert, M., Rennenberg, H. 2016. Genetic and physiological differences of European beech provenances ( $F$. sylvatica L.) exposed to drought stress. - Forest Ecology and Management, 361, 226-236. https://doi.org/10.1016/j.foreco.2015.11.014. 
Fulín, M., Čáp, J., Cvrčková, H., Novotný, P., Máchová, P., Dostál, J., Frýdl, J. 2016. Genetic characterization of important regional beech populations in the Czech Republic. (Genetická charakterizace významných regionálních populací buku lesního v České republice). - Specialized map with extended content. Strnady, VÚLHM. 52 p. (In Czech).

Gömöry, D., Ditmarová, L., Hrivnák, M., Jamnická, G., Kmet, J., Krajmerova, D., Kurjak, D. 2015. Differentiation in phenological and physiological traits in European beech (Fagus sylvatica L.). - European Journal of Forest Research, 134, 1075-1085. https://doi. org/10.1007/s10342-015-0910-2.

Hartl, D.L., Clark, A.G. 2007. Principles of Population Genetics. $4^{\text {th }}$ Edition. Sunderland, Sinauer Associates. 652 pp.

Hasenkamp, N., Ziegenhagen, B., Mengel, C., Schulze, L., Schmitt, H.-P., Liepelt, S. 2011. Towards a DNA marker assisted seed source identification: A pilot study in European beech (Fagus sylvatica L.). - European Journal of Forest Research, 130, 513-519. https:/ / doi. org/10.1007/s10342-010-0439-3.

Janković, I.K., Nonić, M., Devetaković, J., Ivetić, V., Šijačić-Nikolić, M., Aleksić, J.M. 2019. Technical overview of nuclear microsatellites for Fagus sp., and their utility in F. sylvatica from the central Balkans (Serbia). Scandinavian Journal of Forest Research, 34, 545-556. https://doi.org/10.1080/02827581.2 019.1623305.

Jump, A.S., Hunt, J.M., Martínez-Izquierdo, J.A., Peñuelas, J. 2006a. Natural selection and climate change: Temperature-linked spatial and temporal trends in gene frequency in Fagus sylvatica. - Molecular Ecology, 15, 3469-3480. https://doi.org/10.1111/j.1365294X.2006.03027.x.

Jump, A.S., Hunt, J.M., Peñuelas, J. 2006b. Rapid climate change-related growth decline at the southern range edge of Fagus sylvatica. - Global Change Biology, 12, 2163-2174. https://doi. org/10.1111/j.1365-2486.2006.01250.x.

Kalinowski, S.T., Taper, M.L., Marshall, T.C. 2007. Revising how the computer program CERVUS accommodates genotyping error increases success in paternity assignment. Molecular Ecology, 16, 1099-1106. https:// doi.org/10.1111/j.1365-294X.2007.03089.x.

Kempf, M., Konnert, M. 2016. Distribution of genetic diversity in Fagus sylvatica at the north-eastern edge of the natural range. Silva Fennica, 50, article ID 1663. https://doi. org/10.14214/sf.1663.

Lefèvre, S., Wagner, S., Petit, R.J., De Lafontaine, G. 2012. Multiplexed microsatellite markers for genetic studies of beech. - Molecular Ecology Resources, 12, 484-491. https://doi. org/10.1111/j.1755-0998.2011.03094.x.
Leuschner, C., Meier, I.C., Hertel, D. 2006. On the niche breadth of Fagus sylvatica: soil nutrient status in 50 Central European beech stands on a broad range of bedrock types. - Annals of Forest Science, 63, 355-368. https://doi. org/10.1051/ forest:2006016.

Magri, D., Vendramin, G.G., Comps, B., Dupanloup, I., Geburek, T., Gömöry, D., Latałowa, M., Litt, T., Paule, L., Roure, J.M., Tantau, I., van der Knaap, W.O., Petit, R.J., de Beaulieu J.-L. 2006. A new scenario for the Quaternary history of European beech populations: palaeobotanical evidence and genetic consequences. - New Phytologist, 171, 199-221. https://doi. org/10.1111/j.1469-8137.2006.01740.x.

Ministry of Agriculture. 2019. Ministry of Agriculture of the Czech Republic. - Report on forest management of the Czech Republic in 2018. (Zpráva o stavu lesa a lesního hospodářství České republiky v roce 2018). Prague, Ministerstvo Zemědělství ČR. 111 pp. (In Czech).

Nei, M. 1972. Genetic distance between populations. - The American Naturalist, 106, 283-292. https://doi.org/10.1086/282771.

Nei, M. 1987. Molecular Evolutionary Genetics. New York, Columbia University Press. 514 pp.

Pastorelli, R., Smulders, M.J.M., Westende, W.P.C., Vosman, B., Giannini, R., Vettori, C., Vendramin, G.G. 2003. Characterization of microsatellite markers in Fagus sylvatica L. and Fagus orientalis Lipsky. - Molecular Ecology Notes, 3, 76-78. https://doi.org/10.1046/ j.1471-8286.2003.00355.x.

Paule, L. 1997. Gene conservation in European beech (Fagus sylvatica L.). - Bocconea, 7, 367-381.

Peakall, R., Smouse, P.E. 2006. GenALEx 6: Genetic analysis in Excel. Population genetic software for teaching and research. - Molecular Ecology Notes, 6, 288-295. https://doi.org/10.1111/ j.1471-8286.2005.01155.x.

Peakall R., Smouse, P.E. 2012. GenALEx 6.5: Genetic analysis in Excel. Population genetic software for teaching and research - an update. - Bioinformatics, 28, 2537-2539. https://doi. org/10.1093/bioinformatics/bts460.

Piotti, A., Leonardi, S., Buiteveld, J., Geburek, T., Gerber, S., Kramer, K., Vettori, C., Vendramin, G.G. 2012. Comparison of pollen gene flow among four European beech (Fagus sylvatica L.) populations characterized by different management regimes. - Heredity, 108, 322-331.

Pluess, A.R., Määttänen, K. 2013. Characterization of eighteen novel microsatellite markers and multiplex PCR protocol for Fagus sylvatica. Conservation Genetics Resources, 5, 311-314. https:/ / doi.org/10.1007/s12686-012-9791-6.

Scalfi, M., Troggio, M., Piovani, P., Leonardi, S., Magnaschi, G., Vendramin, G.G., Menozzi, P. 2004. A RAPD, AFLP and SSR linkage map, and QTL analysis in European beech (Fagus sylvatica L.). - Theoretical and Applied Genetics, 108, 433441. https:/ / doi.org/10.1007/s00122-003-1461-3. 
Seifert, S., Vornam, B., Finkeldey, R. 2012. DNA sequence variation and development of SNP markers in beech (Fagus sylvatica L.). European Journal of Forest Research, 131, 1761-1770. https://doi.org/10.1007/s10342012-0630-9.

Sjölund, M.J., Jump, A.S. 2015. Coppice management of forests impacts spatial genetic structure but not genetic diversity in European beech (Fagus sylvatica L.). - Forest Ecology and Management, 336, 65-71. https://doi. org/10.1016/j.foreco.2014.10.015.

Tanaka, K., Tsumura, Y., Nakamura, T. 1999. Development and polymorphism of microsatellite markers for Fagus crenata and the closely related species, F. japonica. - Theoretical and Applied Genetics, 99, 11-15.

Thiebaut, B., Lumaret, R., Vernet, P. 1982. The bud enzymes of beech (Fagus sylvatica L.) genetic distinction and analysis of polymorphism in several French populations. - Silvae Genetica, $31,51-60$.
Tomášková, I. 2004. Evaluation of changes in the tree species composition of Czech forests. Journal of Forest Science, 50, 31-37.

Vettori, C., Vendramin, G.G., Anzidei, M., Pastorelli, R., Paffetti, D., Giannini, R. 2004. Geographic distribution of chloroplast variation in Italian populations of beech (Fagus sylvatica L.). - Theoretical and Applied Genetics, 109, 1-9. https://doi.org/10.1007/ s00122-004-1609-9.

von Wühlisch, G. 2008. EUFORGEN Technical Guidelines for Genetic Conservation and Use for European Beech (Fagus sylvatica). Rome, Bioversity International. 6 pp.

Vornam, B., Decarli, N., Gailing, O. 2004. Spatial distribution of genetic variation in a natural beech stand (Fagus sylvatica L.) based on microsatellite markers. - Conservation Genetics, 5, 561-570. https:/ / doi.org/10.1023/ B:COGE.0000041025.82917.ac.

Wang, K.S. 2004. Gene flow in European beech (Fagus sylvatica L.). - Genetica, 122, 105-113. https://doi.org/10.1023/ B:GENE.0000040999.07339.d4. 